\title{
Community Perception of the Security and Acceptance of Mobile Banking Services in Bahrain: An Empirical Study
}

\author{
Ahmad S. Mashhour, PhD \\ IS Department, \\ University of Bahrain
}

\author{
Zakarya Saleh, $\mathrm{PhD}$ \\ IS Department, \\ University of Bahrain
}

\begin{abstract}
Bahraini banks and financial organizations have applied remote enabled service using the internet and a mobile device to increase efficiency, reduce costs and improve quality of services. There is need for these organizations to identify factors that persuade customers and raise their attitudes towards adoption and usage of these services.

This study identifies the most important factors affecting customer attitudes towards mobile banking acceptance in Bahrain. The model formulated in this research presents and empirically examined the factors influencing mobile banking adoption behavior on customers. The model was tested with a survey sample of 300 banking customers. The findings of the study indicate that wireless connection quality, mobile banking awareness, the social influence, mobile self-efficacy, trust, and resistance to change have significant impact on the attitudes towards the likelihood of adopting mobile banking. Model developed is an extension to the Technology Acceptance Model (TAM). Data analysis is based on the Statistical Package for Social Science (SPSS).
\end{abstract}

Keywords-Adoption factors; Bahrain community; Mobile Banking Services; Perceived Usefulness (PU); Perceived Ease of Use (PEOU); Technology acceptance model (TAM)

\section{INTRODUCTION}

Mobile banking (m-banking) refers to the use of a smartphone or other cellular device such as tablet and Personal Digital Assistant (PDA) to perform online banking tasks from any place and any time. Mobile banking typically operates across all major mobile providers through one of three ways: SMS messaging; mobile web; or applications. Developed Mobile SMS text and alert is the simplest, allowing the user to transfer fund or access account information via text message. Mobile web is the second mobile banking option, which is similar to online account access from a home-based computer, this option allows for checking balances, bill payment and account transfers simply by logging into the user's account via a mobile web browser[1]. Mobile banking applications for Android, iPhone and Blackberry, connect the user directly to the bank server for complete banking functionality without having to navigate a mobile web browser.

Smartphone, Tablets and apps have spread the use of online banking and changed the way people bank. The number of mobile banking users has grown from 17.8 million in 2010 to 53.1 million in 2013 [2]. This increase can be recognized to the growth in smart phones industry and banking apps that have been developed by different banking organization. Advantages of mobile banking are numerous for both bankers and customers. For the bankers, mobile banking brings a range of benefits right from reducing costs, achieving greater customer satisfaction to bringing more customers into their crease. For the customer, it gives them an easy access to their account as they no longer have to go the actual banks to make their transactions. Service providers also benefit from mobile banking as it regarded as the best way of achieving growth. However, there are still issues facing banking organizations such as security and privacy $[3,4,5]$.

Bahrain is considered a main center of the financial industry of the Arabian Gulf States which incents most Bahraini banks to adopt mobile banking (M-banking) services to satisfy the need of their customers. Bahrain's growing reputation as a center of financial excellence in the region is reflected by the steady increase of financial institutions registered in the Kingdom providing a variety of new and traditional banking services. There are 55 banks operating in Bahrain [6], and have increasingly adopted Internet and mobile devices in their services. Bahrain has the highest penetration Internet access rate in the area and rated $27^{\text {th }}$ in the world out of 142 countries by the World Economic Forum's Network Readiness Index [6-7].

Although previous studies have addressed an extensive range of factors related to user adoption of information technology applications and products worldwide and including the Arabian Gulf states, developing a model that captures salient aspects of mobile banking in Bahrain and all factors affecting the adoption of mobile banking is suggested and in fact needed by both business and their customers. The main objective of this study is to understand the factors that affect users' adoption of mobile banking by developing a mobile banking adoption model (for Bahraini community) that raises their attitudes towards the usage of mobile banking services. To achieve the research objectives, one main research question was addressed: "What factors affect the adoption of mobile banking from the user's perspective?"

The remainder of the paper consists of the following sections: The next section presents literature review, followed by operation overview of online banking and security concerns. The next section presents research methodology which includes model development, and experiment design 
and implementation, followed by results discussion, and conclusions.

\section{LITERATURE REVIEW AND THEORETICAL FRAMEWORK}

According to survey by U.S Federal Reserve 2012 report prepared by Statista.com [8] and results shown in figure 1, a significant number of mobile phone users have already adopted mobile banking. The expected percentage of mobile owner who is planning to use mobile banking by 2017 will reach $51 \%$. From the same survey, mobile banking is highly correlated with age and education; individuals between ages 18 and 29 account for approximately $44 \%$ of mobile banking users. 73 percent of all mobile banking users have at least some college education, but this education group represents only $60 \%$ of all mobile phone users, and the use of mobile banking is generally unrelated to household income. Undoubtedly, checking financial account balances or transaction inquiries were the most common mobile banking activity, with 90 percent of mobile banking users having performed this function in the last two years.

A study by Hassan et al. [9] investigated factors influencing the adoption of mobile banking services in Bangladesh and concluded that five factors affects user adoption. These are: perceived usefulness, subjective norm, perceived ease of use, perceived credibility, consumer awareness about mobile banking and perceived risks associated with mobile banking. A study by Soufi \& Ali [10] concluded that the intention to adopt mobile banking in Bahrain is mainly affected by specific factors which are: Perceived Usefulness and Ease of Use.

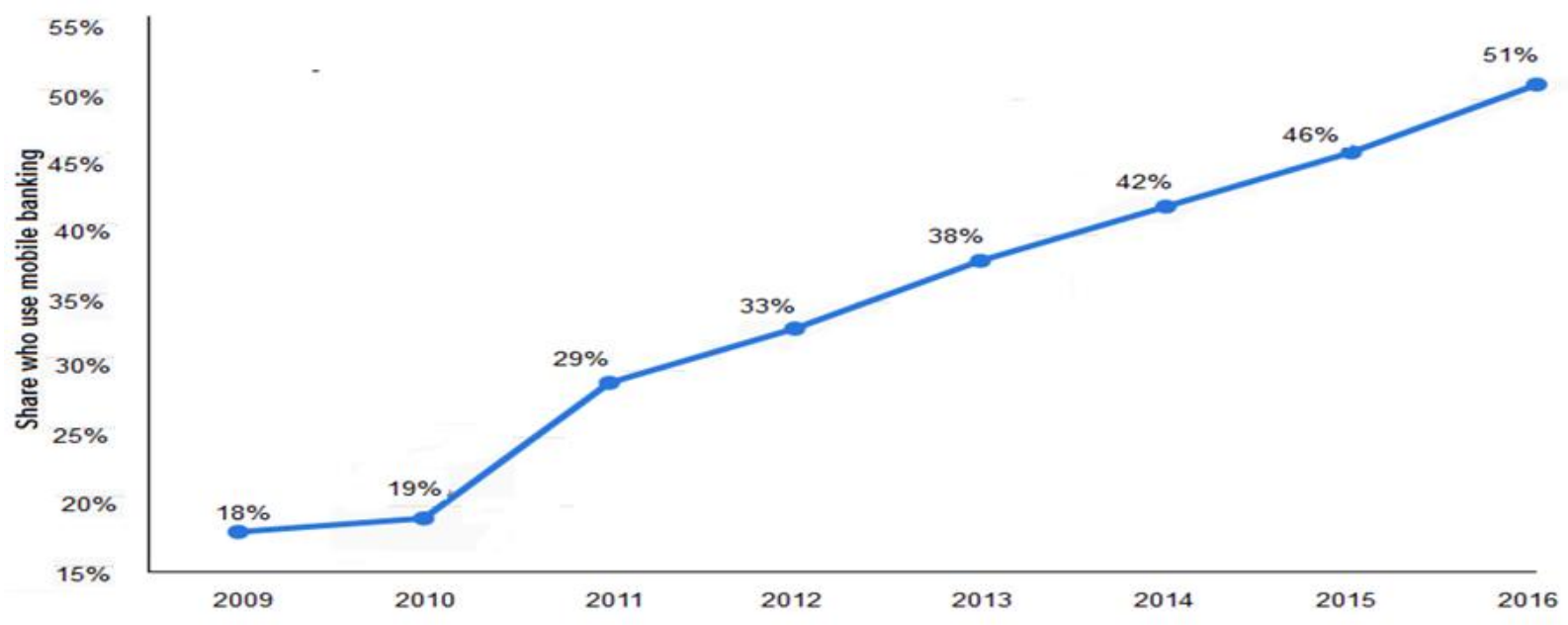

Fig. 1. Number of U.S. Mobile Users for the Period 2009-2011 [8]

A study by Bankole at al. [11] explores factors that influence adoption of mobile banking in Nigeria. Research results showed the existence of a causal relationship between perceived quality, satisfaction, and commitment in the context of mobile banking. His results showed that the perceived quality heavily influences the commitment of customers and its effect is direct and not mediated by satisfaction. A study by Al-Somali et al. [13] was aimed to identify the factors that encourage customers to adopt mobile banking in Saudi Arabia. It revealed that there are many factors that can influence the acceptance of mobile banking in Saudi Arabia, these factors include: quality of the Internet connection, awareness of services, trust, social influence, resistance to change, the technology self-efficacy and demographic characteristics. Alalwan et al. [14] studied predictive factors influencing customer intention and adoption of mobile banking in Jordan. The study concluded that trust is a crucial factor influencing behavioral intention to use mobile banking. Performance expectancy, hedonic motivation, and facilitating conditions are also positively influence the adoption of mobile banking.

\section{OPERATION OVERVIEW}

Mobile Banking is designed for mobile phone users and offers them services that enable them to conduct their financial transactions through a mobile device such as a mobile phone or tablet. The architecture of the Mobile Banking System is depicted in Figure 2, which shows the main functional components, their roles and contribution within the system.

The Mobile Banking Equipment is what is at the enduser's hand to access the information and services provided by the system. The Mobile Banking Equipment displays the menu and performs secure short message creation and transmission based on the user's selection. The Mobile Banking Platform is split into two functional blocks, which may be separated and operated by the Network Provider and the Service Provider respectively.

The Mobile Banking Platform transfers the short message received from the Mobile Banking Equipment into conformant commands of a selected banking protocol. Interaction between User and Service Provider system is supported by multilevel dialogs. The Bank Account Server as part of the system provides the respective banking support. It receives the instructions to provide the necessary functions to be performed on the bank accounts and communicates the results and status back to the Mobile Banking Platform. The Mobile Banking System supports communication with other servers, such as Internet Information Servers. These participate in the environment and contribute other services and information to enhance the service offering to the user. 


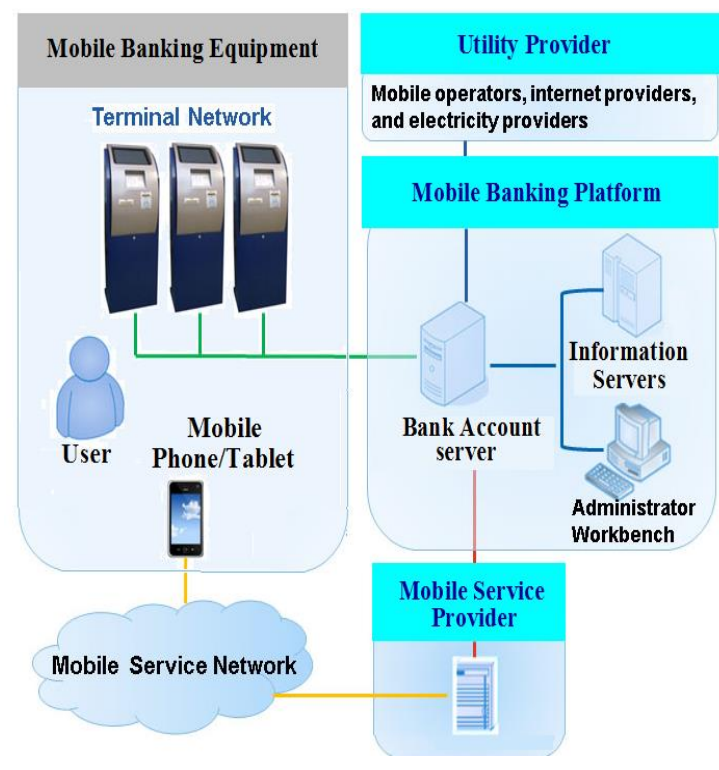

Fig. 2. Mobile Banking System Architecture

Besides viewing account balances and detailed account history, some of the banks in Bahrain (e.g. HSBC) provide several service to their customers which includes moving money between accounts, pay bills, check exchange rates and use the built-in currency calculator, receive secure messages from the bank and send requests from the mobile devices.

\section{MobIle PHONES SECURITY CONCERNS}

Security of financial communications, where the transactions are performed remotely, then transmitting this sensitive information over the air, is a complicated challenge that needs to be the concern of the mobile application developers, the wireless network service providers and the banks' information technology departments. A PwC financial mobile services consumer survey of Canadian and US consumers reveals that security risk and fraud is a top concern for $78 \%$ of respondents when it comes to mobile payments. The survey also shows that $67 \%$ of those surveyed would prefer that their mobile payments be enabled by their banks [15]. IO Active security assessment company, published a report on the sort of security users can expect when conducting mobile banking on an iPhone or iPad, indicating that $70 \%$ of the apps offered no support at all for two-factor authentication and $40 \%$ of the apps did not validate the authenticity of SSL certificates presented, making them susceptible to Man in The Middle attack [16]. Someone performing a man-in-the-middle (MITM) attack on HTTPS traffic (i.e. HTTP over SSL) would be able to see all content of the encrypted communication, including transmitted usernames and passwords [17]. The fact is HTTPS certificates rely on a chain of trust, and validating that chain is important.

Identity modules (universally known as SIM cards), that interoperate with GSM cellular networks, incorporate a SIM File System (see figure 3), resulting in various types of digital evidence, including mobile banking transactions that could exist in elementary data files scattered throughout the file system and be recovered from the Universal Integrated Circuit Card (UICC).

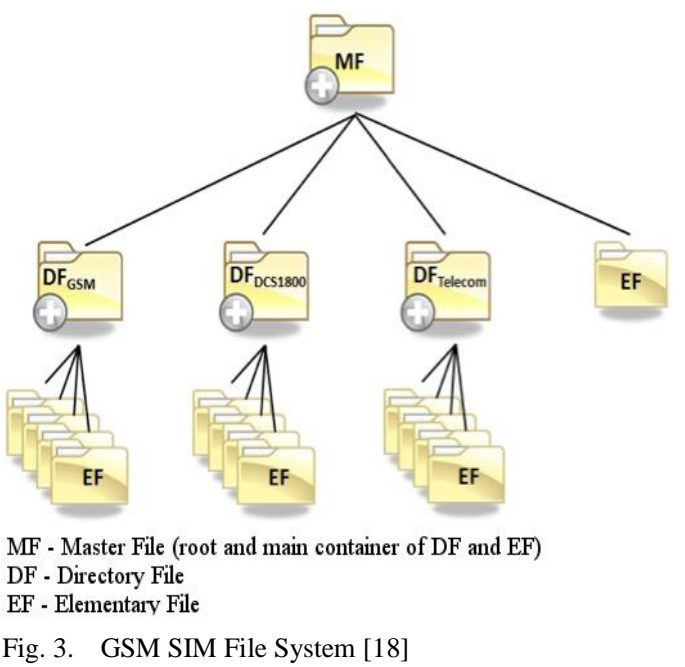

In addition, some of the same information held in the UICC may be maintained in the memory of the mobile device and encountered there as well [18]. Besides the standard files defined in the GSM specifications, a UICC may contain several general categories of data that could be found in standard elementary data files of a UICC. This information could include service-related information (e.g. the unique identifiers for the UICC), the Integrated Circuit Card Identification (ICCID) and the International Mobile Subscriber Identity (IMSI) (e.g. Phonebook, call information such as Abbreviated Dialing Numbers (ADN) and Last Numbers Dialed (LND)), and the messaging information including both Short Message Service (SMS) text messages and Enhanced Messaging Service (EMS) simple multimedia messages. The USIM application supports the storage of links to incoming (EFICI) and outgoing (EFOCI) calls (the EFICI and EFOCI are each stored using two bytes. The first byte points to a specific phone book and the second points to an abbreviated dialing number (EFADN) entry), as well as location information including Location Area Information (LAI) for voice communications and Routing Area Information (RAI) for data communications which indicates that mobile transactions data and information could be easily retrieved using some of the available tools (including commercial and open source tools) that are normally intended for device management, testing, and diagnostics. Example of the tools that can be used for the black box analysis would be otool (object file displaying tool), Burp pro (proxy tool), or SSH [16].

\section{DeVelopment of THE ReSEARCH Model}

The Technology Acceptance Model (TAM) proposed by Davis [19] is an information systems model used to explain or predict users' motivations to accept and use a technology. TAM, as illustrated in Figure 4, is one of the most utilized models used to determine Information Systems/Information Technology (IT/IS) acceptance. Many previous studies have adopted and expanded this model which was empirically proven to have high validity [20-28]. The model identifies Perceived Usefulness (PU) and Perceived Ease of Use (PEOU) as key factors that influence acceptance of a certain technologies. 


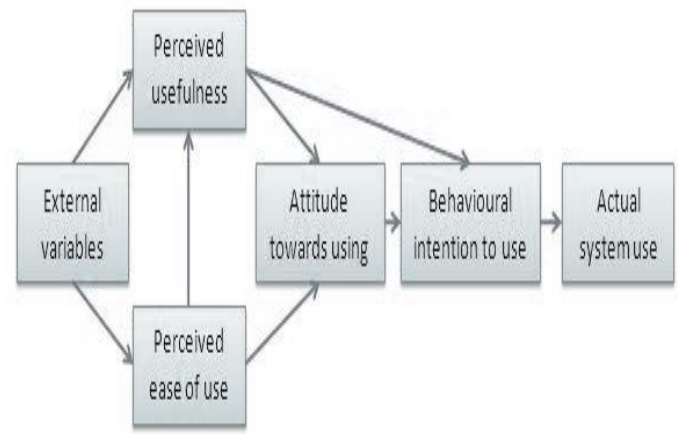

Fig. 4. Technology Acceptance Model, source: Davis et al. [22] 4

As defined by Davis [19], perceived ease of use and perceived usefulness are the two main factors that influence an individual's attitudes towards intention to use IT/IS (i.e., mobile banking system services). These attitudes will in turn influence the actual use of mobile banking. This research defines PU in the context of mobile banking as the degree to which a user believes that using a mobile banking system service would enhance banking services usability. We also assume that mobile banking is more likely to be adopted if they are easy to use. Therefore, PEOU is defined in this research as the degree to which a user believes that using a mobile banking system service or technology would be free from effort. However, TAM does not take into confederations the security aspects of the technology, and mobile banking is exposed to more security issues because wireless circuits are easier to tap than their hard-wired counterparts. In addition, despite the concerted efforts to secure the transmission of sensitive information over handheld devices, there is still the risk of physically loosing of the device. Accordingly, this study proposes an extended version of the Technology Acceptance Model (TAM). The proposed variables were tested and verified and the complete set of the variables are collected and tested on Bahraini community's acceptance of mobile banking. Several hypotheses have been constructed in the model for testing mobile banking adoption in Bahrain.

\section{A. Demographic factors}

Many studies recognized that demographic factors impact heavily on consumer attitudes and behavior regarding technology acceptance [29-31]. According to these studies young, educated, and wealthy consumers are the most likely to adapt the technologies. Therefore, the following hypotheses have been developed.

H1-A: Age positively affects customer's attitude towards using mobile banking.

H1-B: Gender has no impact on the customer's attitude towards using mobile banking.

H1-C: the level of Income has a significant impact on the customer's attitude towards using mobile banking.

H1-D: The level of education has a positive impact on the customer's attitude towards using mobile banking.

\section{B. External Factors}

1) The quality of the Internet connection (QI) is an essential component for any Internet-based application. Without a proper Internet connection the use of mobile banking is not possible. Some studies confirm that there is a significant relationship between the speed of Internet access and the use of mobile banking services [31-32].

$\mathrm{H} 2$ : Perceived quality of the Internet connection (QI) has a positive impact on customer's perceived ease of use.

2) The technology self-efficacy (SE) is an individual's belief about his/her ability to successfully use the technological service to accomplish a specific task. Davis et al. [22] found that 'The technology self-efficacy' and 'perceived ease of use' are related. There is empirical evidence in previous studies that the technology self-efficacy has a positive impact on perceived usefulness and perceived ease of use [33-36].

H3: The technology self-efficacy (SE) has a positive impact on customer's perceived ease of use.

3) Awareness of services (AW): According to Sathye [30] \& Al-Somali et al. [13], awareness of service has direct influence on user intention to use the technology.

H4: Awareness of services (AW) and benefits has a positive impact on customer's perceived usefulness.

4) Social Influence (SI) or (Image) is the degree to which a potential user perceives the usage of a technologically based innovation as adding prestige to his social image. Customers may have unfavorable or favorable perceptions towards mobile banking use because of the perceptions of a family member, acquaintances or peers influence. Davis et al. [22] believed that in some circumstances people might use a technology to comply with others' mandates rather than their own feelings and beliefs.

H5: Social Influence (SI) has a positive impact on customer's perceived usefulness.

5) Trust and security (TRS): Mobile banking services carry benefits as well as risks. Trust and security are related factors, and thus, are important in the acceptance of mobile banking. Trust has been accepted as a critical element in mobile banking services due to the fact that transactions are characterized as a process that involves uncertainty and risk and therefore, trust is considered as the most effective means of reducing uncertainty and risk [36]. Generally, consumer trust has been identified as a key to the development of Internet services [36-41].

H6: Customers Trust in secured (TRS) mobile banking has a positive impact on their attitudes towards using mobile banking.

6) Convenience is viewed as a very important advantage of mobile banking especially when users want to be able to have access to services anywhere at any time [39].

$\mathrm{H} 7$ : Convenience (CNV) is Positively Related to perceived ease of use (PEOU). 
7) Perceived ease of use (PEOU): This study suggests that mobile banking system requires less effort to use, learn, and train. According to Padachi et al., [42] ease of use is a significant factor in the adoption of e-Banking. Safeena et al. [43], and Liao and Wong [44] Stated that perceived ease of use has a strong and positive influence on customer's intention to adopt and use internet services.

H8: Customer's perceived ease of use in mobile banking system positively impact customer's attitude towards using mobile banking.

8) Perceived usefulness (PU) of mobile banking: Several studies showed that perceived usefulness influence customer interactions with internet banking [13,42,44], and these studies beleive that perceived usefulness affects the adoption of mobile banking services. Therefore a new hypothesis is added:

H9: Customer's Perceived Usefulness (PU) impacts positively the intention to use mobile banking.

9) Customer's attitude towards using mobile banking (ATT): Researchers found that users' attitude towards the acceptance of a new information system (IS) has a critical impact on its success [13, 45-46]. Celik [47] stated that perceived usefulness and perceived ease of use are direct determinants of customers' attitudes towards using the technology. Yap, et al. [48] stated that traditional service quality and website features such as PU, PEOU and PC (Perceived credibility) gives customer confidence and build trust in the technology. The following hypothesis is added:
H10: Customer's Attitude (ATT) towards using mobile banking has a positive impact on his/her behavioral intention to use it. Figure (4) next depicts the proposed model.

\section{EXPERIMENT DESIGN}

A sample of 300 participants was randomly chosen from the Bahrain community. All participants were bank customers selected randomly from universities, companies and Internet forums and are supposed to have some experience in using the Internet. Two hundred and forty six usable responses were collected, yielding a response rate of $82 \%$.

The questionnaire is divided into three main sections according to Mobile banking service usage. The selection of the questionnaire items were collected form latest case studies and literature review which is considered the main source of information in developing the research questionnaire and then the research model $[49,50]$. The questionnaire begins with general (demographic) section consist of questions which collect information about gender, age, level of education, income, preferred methods of performing banking transactions, computer literacy level, bank visiting frequency, user bank account, Internet knowledge a usage, and the type of users. The second set of questions are related services provided to users of mobile banking; it consists of several questions grouped into ten groups. The third set of questions belongs to the people who do not use the mobile banking services, and it includes challenges to mobile banking services.

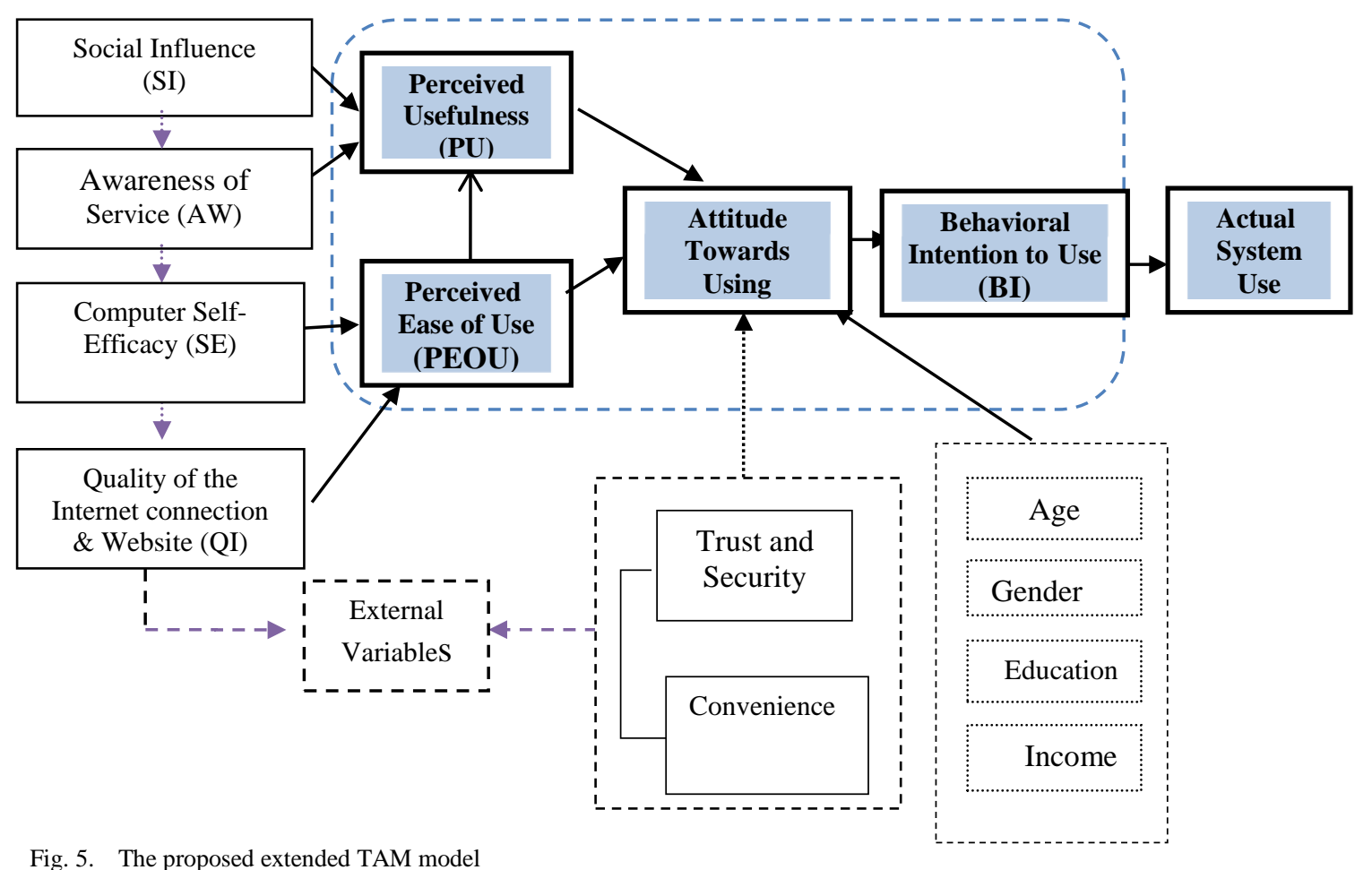

Fig. 5. The proposed extended TAM model 


\section{RESULTS AND DISCUSSION}

The hypotheses were tested with an online survey involving 246 banking customers residing in the Kingdom of Bahrain. Collected data were analyzed using SPSS (Statistical Package for Social Science) Version 19 by applying several statistical tests including descriptive statistics and Chi-Square test. The descriptive statistics of the respondents' demographic characteristics were analyzed and presented first in table 1 shown below and summary of other hypothesis analysis are presented next.

\section{A. Demographic Characteristics Analysis}

43.92 percent of the respondents were male and the largest proportions $(56.1 \%)$ of respondents were females. The largest proportion $(65.9 \%)$ of respondents by age group, were those in the 18-25 years old category. The survey respondents were generally well educated with over $12.2 \%$ holding an advanced degree and $64.2 \%$ having a 4 -year first degree. The results indicate that the largest proportion (44.0\%) of respondents had advanced computer literacy and only a tiny proportion claimed to have no or little computer ability. Based on the income more than half of the respondents $(53.0 \%)$ earn less than 400 BD (1300 US dollar) monthly.

Chi-square test results for demographic factors are shown in table 2. From the table, the Sig. value is close to 0.000 for gender and income, 0.033 for Age (which is less than 0.05, the accepted criterion), and equal to 0.247 for education. Therefore the results are significant for gender, age, income and related to the intention to use mobile banking, while education is not significant and therefore does not affect intention to use the internet banking. Therefore, H1-A, H1-B and $\mathrm{H} 1-\mathrm{D}$ have been confirmed (not rejected) while $\mathrm{H} 1-\mathrm{C}$ is rejected.

TABLE I. DEMOGRAPHIC CHARACTERISTICS OF MOBILE BANKING USAGE

\begin{tabular}{|c|c|c|c|c|c|}
\hline \multicolumn{2}{|c|}{ Demographic factor } & \multirow{2}{*}{$\begin{array}{l}\begin{array}{l}\text { Using mobile banking } \\
\text { services }\end{array} \\
60\end{array}$} & \multirow{2}{*}{$\begin{array}{l}\text { Do not use mobile banking } \\
48\end{array}$} & \multirow{2}{*}{$\begin{array}{l}\text { Total } \\
108\end{array}$} & \multirow{2}{*}{$\begin{array}{l}\text { Percent }(\%) \\
43.91\end{array}$} \\
\hline \multirow{3}{*}{ Gender } & Male & & & & \\
\hline & Female & 28 & 110 & 138 & 56.09 \\
\hline & Total & 88 & 158 & 246 & 100.0 \\
\hline \multirow{5}{*}{ Age } & Between $18-25$ & 44 & 118 & 162 & 65.84 \\
\hline & Between $25-35$ & 24 & 16 & 40 & 16.26 \\
\hline & Between $35-45$ & 12 & 15 & 27 & 11.38 \\
\hline & Above 45 & 8 & 9 & 17 & 06.52 \\
\hline & Total & 88 & 158 & 246 & 100 \\
\hline \multirow{6}{*}{ Education } & High school & 11 & 19 & 30 & 12.20 \\
\hline & Bachelor's & 38 & 110 & 158 & 64.23 \\
\hline & Master's & 14 & 8 & 22 & 8.95 \\
\hline & Doctoral & 2 & 2 & 4 & 3.25 \\
\hline & Others & 14 & 18 & 32 & 11.83 \\
\hline & & 44 & 79 & 246 & 100 \\
\hline \multirow{3}{*}{ Income } & less than $400 \mathrm{BD}$ monthly & 34 & 97 & 131 & 53.25 \\
\hline & $\begin{array}{l}\text { Between } 400-800 \mathrm{BD} \\
\text { monthly }\end{array}$ & 26 & 61 & 87 & 35.37 \\
\hline & over 800 BD monthly & 14 & 14 & 28 & 11.38 \\
\hline Total & & 74 & 172 & 246 & 100 \\
\hline
\end{tabular}

TABLE II. PEARSON CHI-SQUaRe TESTS For DEMOgraPhic VARIABles

\begin{tabular}{|l|l|l|l|}
\hline Factor & Value & df & Asymp. Sig. (2-sided) \\
\hline H1. Gender & 16.397 & 1 & .000 \\
\hline H2. Age & 8.735 & 3 & .033 \\
\hline H3. Education & 5.414 & 4 & .247 \\
\hline H4. Income & 37.457 & 3 & .000 \\
\hline
\end{tabular}

\section{B. Significance Analysis of Research Hypotheses}

First table 3 shows averages calculation for the tested variables, the correlation and Chi-Square tests between the hypotheses has been calculated and presented next. Tables 4 and 5 presents the results of asymptotic analysis and chisquare test analysis of the data collected from sample users' responses

TABLE III. CAlculated SAmple Averages of the Tested Variables

\begin{tabular}{|c|c|c|c|c|c|c|c|c|c|}
\hline $\begin{array}{r}\text { PU } \\
\text { AVG }\end{array}$ & $\begin{array}{r}\text { PEOU } \\
\text { AVG }\end{array}$ & $\begin{array}{r}\text { BI } \\
\text { AVG }\end{array}$ & $\begin{array}{l}\text { ATT } \\
\text { AVG }\end{array}$ & $\begin{array}{r}\text { QI } \\
\text { AVG }\end{array}$ & $\begin{array}{r}\text { AW } \\
\text { AVG }\end{array}$ & $\begin{array}{r}\text { TRS } \\
\text { AVG } \\
\end{array}$ & $\begin{array}{r}\text { SI } \\
\text { AVG }\end{array}$ & $\begin{array}{l}\text { CNV } \\
\text { AVG }\end{array}$ & $\begin{array}{r}\text { SE } \\
\text { AVG }\end{array}$ \\
\hline 4.8 & 3.4833 & 3.7677 & 3.812 & 3.5134 & 3.4638 & 3.1849 & 3.1506 & 2.71 & 2.8797 \\
\hline 4.4 & 4.3666 & 4.3604 & 4.2918 & 4.1266 & 4.1144 & 3.9638 & 3.9656 & 3.49 & 3.9486 \\
\hline 4 & 3.9166 & 3.6823 & 3.6 & 3.3777 & 3.2444 & 3.0492 & 3.0968 & 3.11 & 3.0633 \\
\hline
\end{tabular}


According to table 4 all the above hypothesizes (H2 - H10) have an Approx. Sig. close to 0.00 with perceived ease of use, perceived usefulness and behavioral intention to use (BI). So all the above hypothesizes are positively confirmed and are related.

Same conclusion can be obtained from table 5 where H8, H9, H10, have Asymptotic Significance close to 0.00 and an equal Asymptotic Significance for both $\mathrm{H} 6$ and $\mathrm{H} 7$ with
0.005. $\mathrm{H} 2$ and $\mathrm{H} 3$ have an Approx. Sig. with 0.02 and 0.010 respectively. From the table all results are significant, i.e. (chisquare is less than or equal to 0.05). This confirms with the results of frequency analysis of the hypotheses.

Table 6 summarizes the hypothesize result which shows that generally Bahraini citizen have a good awareness of mobile banking services.

TABLE IV. PEARSON SyMmETRIC MEASURES

\begin{tabular}{|c|c|c|c|c|}
\hline Hypothesizes path & Value & $\begin{array}{l}\text { Asymp. Std. } \\
\text { Error }\end{array}$ & Approx. T & Approx. Sig. \\
\hline H2: Quality of Internet (QI) AVERAGE $\rightarrow$ PEOU_AVG & .966 & .013 & 24.181 & .000 \\
\hline H3: The technologies self-efficacy (SE)_AVG. $\rightarrow$ PEOU_AVG & .929 & .025 & 16.103 & .000 \\
\hline H4: Awareness of Service(AW)_AVG. $\rightarrow$ PU_AVG & .834 & .062 & 9.800 & .000 \\
\hline H5: Social Influence $(\mathrm{SI})_{2}$ AVG $\rightarrow$ PU_AVG & .822 & .070 & 9.344 & .000 \\
\hline H6: Trust $\&$ Security $($ TSR)_AVG $\rightarrow$ ATT_AVG & .972 & .012 & 26.712 & .000 \\
\hline H7: Convenience (CNV)_AVG $\rightarrow$ ATT_AVG & .842 & .0271 & 22.234 & .000 \\
\hline H8: PEOU_AVG $\rightarrow$ ATT_AVG. & .980 & .007 & 32.140 & .000 \\
\hline H9: PEOU_AVG $\rightarrow$ PU_AVG & .913 & .040 & 14.531 & .000 \\
\hline H10: Attitudes toward using_AVG (ATT) $\rightarrow$ BI_AVG & .993 & .003 & 53.530 & .000 \\
\hline
\end{tabular}

TABLE V. ChI-SQuARE TESTS

\begin{tabular}{|l|l|l|l|}
\hline Hypothesis & Value & df & Asymp. Sig. (2-sided) \\
\hline H2: QI_AVG $\rightarrow$ PEOU_AVG & 1.232 & 1092 & .002 \\
\hline H3: SE_AVG. $\rightarrow$ PEOU_AVG & 1.204 & 1092 & .010 \\
\hline H4: AW_AVG $\rightarrow$ PU_AVG & 5.720 & 520 & .057 \\
\hline H5: SI_AVG $\rightarrow$ PU_AVG & 5.720 & 520 & .057 \\
\hline H6: TRS_AVG $\rightarrow$ ATT_AVG & 1.584 & 1440 & .005 \\
\hline H7: CNV_AVG $\rightarrow$ ATT_AVG & 1.324 & 1092 & .012 \\
\hline H8: PEOU_AVG $\rightarrow$ ATT_AVG & 5.32 & 512 & .000 \\
\hline H9: PEOU_AVG $\rightarrow$ PU_AVG & 5.679 & 364 & .000 \\
\hline H10: ATT_AVG $\rightarrow$ BI_AVG & 1.452 & 1188 & .000 \\
\hline
\end{tabular}

\section{Correlation Analysis of Internal Variables}

Pearson correlations were calculated to identify the correlations between the variables: Perceived Usefulness, Perceived Ease of Use, Behavior Intention, and Attitude towards using mobile banking and to test the hypothesis (H8H11). Results are shown in table 6. Since the highest correlation coefficient is 0.513 which is less than 0.8 , there is no multicollinearity problem in this research. Table 7 summarized the end results of the hypothesis testing.

TABLE VI. HYPOTHESIZES RESULT SUMMARY

\begin{tabular}{|c|c|}
\hline Hypothesizes path & Approved \\
\hline H1-A: Gender $\rightarrow$ ATT & $\checkmark$ \\
\hline H1-B: Age $\rightarrow$ ATT & $\checkmark$ \\
\hline H1-C: Education $\rightarrow$ ATT & $\bar{x}$ \\
\hline H1-D: Income $\rightarrow$ ATT & $\checkmark$ \\
\hline H2: Quality of Internet (QI) $\rightarrow$ PEOU & $\checkmark$ \\
\hline H3: Self-Efficacy (SE) & $\checkmark$ \\
\hline H4: Awareness of Service $(\mathrm{AW}) \rightarrow \mathrm{PU}$ & $\checkmark$ \\
\hline H5: Social Influence(SI) $\quad \rightarrow$ PU & $\checkmark$ \\
\hline $\begin{array}{ll}\text { H6: Trust and Security (TRS) } \rightarrow \text { ATT } \\
\end{array}$ & $\checkmark$ \\
\hline H7:Convenience $(\mathrm{CNV}) \rightarrow$ ATT & $\checkmark$ \\
\hline H8: Perceived Ease of Use (PEOU) $\rightarrow$ ATT & $\checkmark$ \\
\hline H9:Perceived Ease of Use (PEOU) $\rightarrow$ PU & $\checkmark$ \\
\hline H10:Attitudes towards using (ATT) $\rightarrow$ BI & $\checkmark$ \\
\hline
\end{tabular}

TABLE VII. CORRELATION ANALYSIS OF INTERNAL VARIABLES

\begin{tabular}{|c|c|c|c|c|}
\hline Criteria & $\mathrm{PU}$ & PEOU & $\mathrm{BI}$ & ATT \\
\hline $\begin{array}{l}\text { Perceived } \\
\text { Usefulness (PU) }\end{array}$ & 1 & & & \\
\hline $\begin{array}{l}\text { Perceived Ease of } \\
\text { Use (PEOU) }\end{array}$ & .423 & 1 & & \\
\hline $\begin{array}{l}\text { Behavioral } \\
\text { Intension (BI) }\end{array}$ & .513 & .499 & 1 & \\
\hline $\begin{array}{l}\text { Attitude towards } \\
\text { (ATT) }\end{array}$ & -.251 & -.356 & -.474 & 1 \\
\hline Mean & 2.44 & 2.34 & 2.233 & 1.843 \\
\hline Standard Deviation & .654 & .792 & .731 & .258 \\
\hline
\end{tabular}

\section{CONCLUSIONS AND RECOMMENDATIONS}

This research was carried out to study the user acceptance of mobile banking practice in the kingdom of Bahrain. The study examines the factors influencing user to adopt mobile banking technology services, as well as influencing users' intentions to adopt mobile banking service and technology. The study finds that mobile banking customers in Bahrain generally have a good awareness of the mobile services that have been provided. However, the study finds that the responders do not use mobile banking services due to many challenges including information security issues. 
The study shows that the most effective challenges (variables) include: trust and lack of experience in using Internet enabled mobile applications. $68.4 \%$ respondents believe don't trust mobile banking, and $36.7 \%$ of them do not have the adequate skills to use the mobile banking technology. For security enhancements, banks and individuals may enhance their mobile devices with add-on security procedures or means.

A variety of login authentication mechanisms are available for mobile devices that could be used as a replacements or supplements to password mechanisms for mobile banking. Mobile banking should support a method to permanently delete all banking history from the mobile devices and all data relates to the transactions to prevent such data from being be recovered from the Universal Integrated Circuit Card. Mobile banking services carries benefits as well as risks. Hence, it is the responsibility of the bankers to recognize, manage and to address banking institutions in cautious and sensible way according to the fundamental characteristics and challenges of mobile banking services. The future of banking is driven by young professionals today who will be the significant drivers of retail banking revenues tomorrow by using their smart phones. Understanding what this group wants will differentiate the winners from the losers in the business of banking.

\section{REFERENCES}

[1] M. Monahan, "What Are The Three Big Trends In Mobile Banking In 2014? ", Javlin Strategy \& Research,2014. Https://Www.Javelinstrategy.Com/Blog/2014/02/18/

[2] Monitise/Future, "Foundation, Emerging Trends In Mobile Banking" Monitise, Americas, Inc. 2010. Www.Monitise.Com/Resources_Centre_Download/28/Money-O.

[3] J. Puschel, J. A. Mazzon, \& J.M.C. Hernandez, "Mobile banking: Proposition of an integrated adoption intention framework. International Journal of Bank Marketing, 28(5), 389-409, 2010.

[4] Federal Reserve Board reports, "Consumers and Mobile Financial Services", http://www.federalreserve.gov/publications/default.htm.

[5] Juniper Research, "Mobile Banking: Handset \& Tablet Market Strategies 2013-2017- the new juniper report", 2013, Hampshire, UK. http:// www.juniperresearch.com.

[6] Bank Association of Bahrain, 2012. http:// www.banksbahrain.org.

[7] World Economic Forum, "The Global Information Technology Report", 2014. http://www.weforum.org/ reports/global information-technologyreport-2014.

[8] Statista, the Statistics Portal, "Percentage of U.S. mobile phone users who use mobile banking from 2009 to 2016", 2015. http://www.statista.com/statistics/244414/percentage-of-us-mobilephone

[9] M. Hassan, A. Rahman, S. Afrin, \& M. Gulam Rabbany, "Factors Influencing the Adoption of Mobile Banking Services in Bangladesh: An Empirical Analysis". International Research Journal of Marketing, 920, 2014. DOI: 10.12966/irjm.02.02.2014

[10] A.Soufi, A., H. Ali, "Customers perception of m-banking adoption in Kingdom of Bahrain: an empirical assessment of an extended TAM model". International Journal of Managing Information Technology (IJMIT), Vol.6, No., 2014.

[11] F. O. Bankole, O. O. Bankole, \& I. Brown, "Mobile banking adoption in Nigeria", The Electronic Journal on Information Systems in Developing Countries EJISDC, 47, 2, pp1-23, 2011.

[12] C. Hamadi, "The Impact of Quality of Online Banking on Customer Commitment". Communications of the IBIMA, IBIMA Publishing",Vol 2., Article ID 844230, 8 pages, 2010, DOI: 10.5171/2010.844230.
[13] S. A. Al-Somali, R. Gholami, \& B. T. Clegg, "An investigation into the acceptance of mobile banking in Saudi Arabia". Technovation, 29(2), pp.130-141, 2009, Elsevier, DOI: 10.1016/j.tecnovation.2008.07.004.

[14] A. Al alwan, Y.K. Dwivedi, \& M.D.Williams, M.D, "Examining Consumer Adoption of Mobile Banking in Jordan". Conference: Proceedings of Academy of Marketing Conference AM 2014. 7th -10th of July 2014, At Bournemouth.

[15] PwC, "Mobile payments: Is trust the key to consumer uptake?", Banking Review, Issue of Winter 2013.

[16] Ariel Sanchez, "Personal banking apps leak info through phone ", Insights, News \& Discoveries from Ioactive Researchers, Issue of January 8, 2014. http://blog.ioactive.com/2014/01/personal-bankingapps-leak-info-through.html.

[17] NETRESEC (2011). "Network Forensic Analysis of SSL MITM Attacks". NETRESEC Network Security Blog. [Online] Available at http:// the WWW on October 2, 2014 at http://www.netresec.com/?page=Blog\&month=2011-03 2014 \& post=Network-Forensic-Analysis-of-SSL-MITM-Attacks

[18] Wayne Jansen, and Rick Ayers, Guidelines on Mobile Device Forensics, NIST Special Publication 800-101, 2014.

[19] F. D. Davis, "Perceived usefulness, perceived ease of use, and user acceptance of information technology", MIS Quarterly, 13(3),1989, 319-339.

[20] P. Y. K. Chau, "An Empirical Assessment of a Modified Technology Acceptance Model", Journal of Management Information Systems, 12 (2), 1996, pp. 185-204.

[21] S. Al-Gahtani, "The applicability of TAM outside North America: An empirical test in the United Kingdom", Information Resources Manage Journal, 2001, 14(3), pp. 37-46.

[22] F. D. Davis, F.D., R. P. Bagozzi, \& P. R. Warshaw, P.R., "User acceptance of computer technology: A comparison of two theoretical models", Management Science, 35(8), 1989, pp. 982-1003.

[23] Davis, F.D. and Venkatesh, V. A., "Critical Assessment of Potential Measurement. Biases in the Technology Acceptance Model: Three Experiments. International", Journal of Human-Computer Studies, 45, 1996, 19-45.

[24] V. Vinkatesh, M. G. Morris, G. B. Davis, F. D. Davis,). "User acceptance of Information Technology: Toward a Unified View", MIS Quarterly, Vol. 27 No. 3, 2003, pp. 425-478.

[25] Dishaw, M., Strong, Diane M., "Extending the technology acceptance model with Task-technology fit constructs", Information \& Management 36 (1), 1999, pp. 9-21.URL http://dx.doi.org/10.1016/S0378-7206 (98)00101-3.

[26] V. Venkatesh, F. D. Davis, "A Theoretical Extension of the Technology Acceptance Model: Four Longitudinal Field Studies", Management Science INFORMS, Vol. 46, No. 2, 2000, pp. 186-204

[27] Y. Malhotra, D. F. Galletta, "Extending the Technology Acceptance Model to Account for Social Influence", Theoretical Bases and Empirical Validation, HICSS, vol. 1, pp.1006, 1999, Thirty-Second Annual Hawaii International Conference on System Sciences-Volume 1.

[28] T. K. Pikkarainen, H. Karjaluoto, S. Pahnila, "Consumer acceptance of mobile banking: an extension of the technology acceptance model", Internet Research, Vol. 14 (3), pp. 224 - 235, 2014.

[29] I. Akman, A. Mishra, " Gender, age and income differences in internet usage among employees in organizations', Computers in Human Behavior, Elsevier, Volume 26, Issue 3, May 2010, Pages 482-490.

[30] M. Sathye, Adoption of Internet Banking by Australian consumer: an empirical investigation. International Journal of Bank Marketing 17(7), 2009, pp. 324-334.

[31] D. El- Kasheir, A. S. Ashour, \& O. M. Yacout, "Factors affecting continued usage of mobile banking among Egyptian customers", Communications of the IBIMA, Vol. 9, 2009, pp 252-263.

[32] T. El-kiki, E. Lawrence, "Mobile User Satisfaction and Usage Analysis Model of m-Government Services", 2007. http://www.m4life.org/proceedings/2006/PDF/11_El-Kiki.pdf

[33] R. Agarwal, V. Sambamurthy, R.M. Stair, Research report: "The evolving relationship between general and specific, The technology self- 
efficacy-An empirical assessment". Information System Research, 11(4), 2000, pp. 418-430.

[34] M. Igbaria, J. Livari, "The effect of self-efficacy on computer useage", Moega, Int. Mgmi Science, Vol.23, No. 6, 2005, pp. 587-606.

Econ. Res., Vol 2(2), 2013, Society of Interdisciplinary Business Research.http://www.sibresearch.org.

[36] Y. H. Kim, D. J. Kim, "A Study of Online Transaction Self-Efficacy, Consumer Trust, and Uncertainty Reduction in Electronic Commerce Transaction". Proceedings of the 38th Hawaii International Conference on System Sciences, 2005.

[37] A. Almogbil, "Security, perception, and practices: challenges facing adoption of mobile banking in Saudi", Unpublished PhD thesis, George Washington University, 2015.

[38] M. S. Shahibi , S. K. W. Fakeh, "Security Factor and Trust in ECommerce Transactions", Australian Journal of Basic and Applied Sciences, 5(12), 2011: 2028-2033.

[39] A. Kagan R. N. Acharya, \& L. S. Rao, "Does Internet Banking Affect the Performance of Community Banks?", Selected Paper prepared for presentation at the American Agricultural Economics Association Annual Meeting, No 19246, 2005. Annual meeting, July 24-27, Providence, RI from American Agricultural Economics Association (New Name 2008: Agricultural and Applied Economics Association). http://purl.umn.edu/19246.

[40] Yousafzai, S.Y., Pallister, J.G., Foxall, G.R. "A proposed model of etrust for electronic banking", Technovation, 23 (11), 2003, pp. 847-860.

[41] Gefen, D., Karahanna, E. \& Straub, D. W., "Trust and TAM in Online Shopping: An Integrated Model", MIS Quarterly, 27, 2003, pp 51-90.

[42] Rojid Padachi, A. Seetanah, " Analyzing the Factors that Influence the Adoption of Internet Banking in Mauritius", Proceedings of the 2007 Computer Science and IT Education Conference,
[35] M. S. M. Arrif, Y. S. Min, N. ZAkuan, N. Shak, "The Impact of Computer Self Efficacy and Technology Acceptance Model on Behavioral Intention in Internet Banking System. Rev.", Integr. Bus.

[43] Safeena, R., Abdullah, K., and Hema, D., "Customer Perspectives on Ebusiness Value: Case Study on Internet Banking", Journal of Internet Banking and Commerce, vol. 15 (1), 2010.

[44] Liao, Z., and Wong, W., "The determinants of customer interactions with internet-enabled mobile banking services", Journal of the Operational Research Society, vol. 59 (9), 2008.

[45] V. Venkatesh, "Determinants of Perceived Ease of Use: Integrating Perceived Behavioral Control, Computer Anxiety and Enjoyment into the Technology Acceptance Model", Information Systems Research, 11, 2000, pp342-365.

[46] M. J. Succi, Z. D. Walter, "Theory of User Acceptance of Information Technologies: An Examination of Health Care Professionals", Proceedings of the 32nd Hawaii International Conference on System Sciences (HICSS), 1999, PP. 1-7.

[47] Celik, H., "Wh1at Determines Turkish customers' acceptance of internet banking?", International Journal of Bank Marketing. Vol. 26 (5), pp353370, 2010.

[48] K. D.Yap, C. Wong, C. Loh, \& R. Bak. "Offline and mobile banking where to draw the line when building trust in e banking", International Journal of Bank Marketing, 28(1), 2010, pp.27-46.

[49] International Finance Corporation (IFC) on Mobile Banking Questionnaire - users http://www.ifc.org/wps/wcm/connect/571b Tool+3.9.+Market+Questionnaire++Users.pdf?MOD=AJPERES 